ISSN : 1412-7601

Volume 3, No.2 September 2017

http://www.ekonobis.unram.ac.id

EKONOBIS

\title{
Analisis Pendapatan Asli Daerah (PAD) Kota Mataram Provinsi Nusa Tenggara Barat
}

\author{
Muhammad Alwi, I Dewa Ketut Yudha S, Lalu Dema Alkandia \\ Universitas Mataram
}

\begin{tabular}{l}
\hline A R T I C L E I N F O \\
\hline Keywords: \\
Effectiveness of \\
Collection, Local Tax, \\
Local Retribution, Local \\
Original Income
\end{tabular}

Received : 28 Juli 2017; Accepted: 21 Agustus 2017; Published: September 2017

ABSTRACT : The purposes of this research are analyse effectivity of the yeals of The

Regional tax, regional retribution and The Regional origin income. To analyse The regional

finance independence and decentralization degree. The main contribution that dominant

to bafferMatarams PAD source from regional tax income that in average has contribution

$48,15 \%$ and other income source of PAD has average contribution $35,83 \%$, while The regional retribution has contribution $12,66 \%$ to PAD and The yeals of The severed Regional Managing has average contribution $3.31 \%$ in period of 2012 to 2015. The Effectivity degree that very effevctive in years of 2012 to 2014 and in 2015 they are in effective category. The ability of Regional Finance in period of 2012 to 2015 included In Low category. Base on The relation pattern of The Central Government and Regional Government Known that in 2012 they have instructive relationship that show that the role of the central gavernment more dominant than Regional government. (mean the Regional Government has not ability to apply Regional otonomy). In 2013 to 2015 the relationship pattern between Central and Regional Government show consultative pattern that mean that the Intervency of the Central Government start to decrease because the Regional Governmenbe assumed little more be able to apply Regional Otonomy. Mataram Fiscal desentralisation degree include in category of lack ability of regional finance in periode of 2012 to 2015. It shows that Mataram regional finance very dependent to Central and Province income source

Kata Kunci :

Efektivitas Pemungutan,

Pajak daerah, Retribusi

Daerah, Pendapatan Asli Daerah
ABSTRAK : Tujuan penelitian untuk menganalisis efektivitas pemungutan pajak daerah, retribusi daerah dan Pendapatan Asli Daerah, mengalisis derajat kemandirian Keuangan daerah. Dan menganalisis derajat desentralisasi Keuangan daerah. Hasil penelitian menunjukkan efektifitas pendapatan asli daerah (PAD) dan pajak daerah dari tahun 2012 sampai tahun 2015 menujukkan rasio efektivitas pemungutan sangat efektif. Sedangkan efektifitas pemungutan retribusi daerah juga menunjukan kriteria tingkat efektifitasnya adalah sangat efektif pada tahun 2012 sampai tahun 2014 sedangkan pada tahun 2015 termasuk kriteria efektif. Kemampuan keuangan daerah pada periode tahun 2012-2015 termasuk dalam kriteria rendah. Berdasarkan pola hubungan antara pemerintah pusat dengan pemerintah daerah diketahui bahwapada tahun 2012 termasuk dalam Pola Hubungan Instruktif yang menunjukkan peranan pemerintah pusat lebih dominan dari pada kemandirian pemerintah daerah (Daerah yang tidak mampu melaksanakan otonomi daerah). Pada tahun 2013 sampai tahun 2015 pola hubungan antara pemerintah pusat dengan pemerintah memperlihatkan pola Hubungan konsultatif yang berarti campur tangan pemerintah pusat sudah mulai berkurang, karena daerah dianggap sedikit lebih mampu melaksanakan otonomi daerah. Derajat desentrasi fiscal kota Mataram termasuk kriteria tingkat kemampuan keuangan daerah yang kurang dalam periode tahun 2012 2015, yang menunjukan bahwa keuangan daerah kota Mataram sangat tergantung pada sumber penerimaan dari pusat maupun pada tingkat provinsi

Corresponding Author:

Alamat : Program Studi Ekonomi Pembangunan, Fakultas Ekonomi dan Bisnis, Universitas Mataram, Jln. Majapahit No. 62 Mataram.

e-mail: cacaalwi.97@unram.ac.id 


\section{PENDAHULUAN}

\section{Latar Belakang}

Sumber-sumber pendanaan pelaksanaan pemerintah daerah adalah Pendapatan Asli Daerah (PAD), dana perimbangan, pinjaman daerah dan pendapatan yang sah lainnya. PAD, yang salah satunya berupa pajak daerah, diharapkan menjadi salah satu sumber pembiayaan penyelenggaraan pemerintahan dan pembangunandaerah,untuk meningkatkan dan memeratakan kesejahteraan masyarakat. Dengan demikian, daerah mampu melaksanakan otonomi, yaitu mampu mengatur dan mengurus rumah tangganya sendiri.

Semakin besar pajak dan retribusi daerah yang diterima otomatis semakin meningkatkan PADnya. Kemandirian Pemkab/Pemkot dapat dilihat dari besarnya PAD yang diperoleh Pemkab/Pemkot. Semakin besar pajak dan retribusi yang diperoleh oleh kabupaten dan kota tersebut dalam membiayai pengeluaran untuk melaksanakan wewenang dan tanggung jawabnya kepada masyarakat seperti membantu dan memfasilitasi sarana dan prasarana masyarakat. Retribusi daerah merupakan pembayaran wajib dari penduduk kepada Negara dikarenakan ada jasa tertentu yang diberikan oleh pemerintah daerah kepada individu secara perorangan. Pungutan dari masyarakat ini akan menjadi sumber pendapatan bagi daerah tersebut, dan bisa dijadikan sumber utama pendapatan daerah selain pajak daerah, bagian laba usaha daerah maupun nilai-nilai PAD yang sah.

Kota Mataram sangat berpotensi untuk meningkatkan penerimaan pajak daerah dan retribusi daerah yang pada giliran akan meningkat Pendapatan Asli Daerah (PAD) Kota Mataram. Kemungkinan ini karena kota Mataram sebagai ibukota Provinsi NTB dan sebagai pusat perdagangan, pemerintah, pendidikan dan jasa pelayanan wisata.

Oleh karena itu, sangat penting menganalisis penerimann pajak daerah dan retribusi daerah dan Pendapatan Asli Daerah di Provinsi Nusa Tenggara Barat yang pada akhirnya akan mempengaruhi total pendapatan daerah pada masa yang akan datang.

\section{Tujuan Penelitian}

1. Untuk menganalisis efektivitas pemungutan pajak daerah, retribusi daerah dan Pendapatan Asli Daerah

2. Untuk mengalisis derajat kemandirian Keuangan daerah Kota Mataram.

3. Untuk mengetahui derajat desentralisasi Fiskal Kota Mataram

\section{LANDASAN TEORI}

\section{Pengertian Pendapatan Asli Daerah (PAD)}

Pengertian pendapatan asli daerah berdasarkan Undang-Undang Nomor 33 Tahun 2004 tentang Perimbangan Keuangan Antara Pusat dan Daerah Pasal 1 angka 18 bahwa "Pendapatan asli daerah, selanjutnya disebut PAD adalah pendapatan yang diperoleh daerah yang dipungut berdasarkan peraturan daerah sesuai dengan peraturan perundangundangan".

Menurut Mardiasmo (2002), "Pendapatan Asli Daerah adalah penerimaan daerah dari sektor pajak daerah, retribusi daerah, hasil perusahaan milik daerah, hasil pengelolaan kekayaan daerah yang dipisahkan, dan lain-lain pendapatan asli daerah yang sah".

\section{Metode Penelitian}

Jenis penelitian ini merupakan penelitian adalah penelitin deskriptif yaitu suatu metode dalam penelitian status kelompok manusia , suatu objek, suatu kondisi, suatu sistem pemikiran ataupun suatu peristiwa pada masa sekarang guna membuat diskripsi, gambaran atau lukisan secara sistimatis, faktual dan akurat mengenai fakta-fakta serta hubungan antara yang diselidiki, dianalisis kemudia disimpulkan (Nazir, 1999;63)

Lokasi Penelitian ini dilaksanakan di Kota Mataram Nusa Tenggara Barat dengan alasan bahwa kota Mataram merupakan Ibu Kota Provinsi NTB dan ssebagai pusat 
pertumbuhan ekonomi, pusat pemerintahan, dan sosial budaya.

Pengumpulan data mengadakan penelitian kepustakaan dengan mempelajari dan mengumpulkan data dari buku-buku dan jurnal yang yang berkaitan dengan masalah yang diteliti.

Jenis data yang digunakan adalah data sekunder. Berupa data APBD tahun 2012 sampai dengan tahun 2015. Data-data yang dibutuhkan dalam penelitian ini bersumber dari Kantor BPS Provinsi NTB dan Kantor Dinas Pendapatan Daerah Kota Mataram serta Instansi yang mengelolah penerimaan pajak daerah dan resteribusi daerah.

1. a. Untuk menganalisis efektivitas pemungutan pajak daerahdigunakan alat analis sebaga berikut :

Rasio Efektivitas Pajak Daerah = Realisasi Penerimaan Pajak Daerah $\times 100 \%$ Target penerimaan Pajak daerah

b. Untuk menganalisis efektivitaspemungutan Retribusidaerahdigunakan alat analis sebaga berikut :

Rasio Efektivitas Retribusi Daerah $=$ Realisasi penerimaa Retribusi Daerah $\times 100 \%$ Target penerimaan Retribusi daerah

c. Untuk menganalisis efektivitas pemungutan PADdi gunakan alat analis sebagai berikut :

Rasio Efektivitas PAD = Realisasi Penerimaan PADx $100 \%$

Target penerimaanPAD

Adapun kriteria efektivitas penilaian kinerja sesuai dengan Keputusan Menteri Dalam Negeri Nomor 690.900-327 Tahun 1996 yaitu

Tabel 1. Kriteria Efektivitas Pemungutan PAD

\begin{tabular}{|c|c|}
\hline Persentasekinerja keuangan & Kriterian penilaian kinerja \\
\hline Lebih dari $100 \%$ & Sangat efektif \\
\hline $90-100 \%$ & Efektif \\
\hline $80-90 \%$ & Cukup efektif \\
\hline $60-80 \%$ & Kurang Efektif \\
\hline Kurang dari $60 \%$ & Tidak efektif \\
\hline
\end{tabular}

Sumber: Keputusan Mendagri Nomor 690.900-327 Tahun 1996

2. Untuk menganalis Rasio Kemandirian Keuangan daerah Kota Mataram digunakan formula Sebagai berikut :

Rasio Kemandirian $=$ Pendapatan Aslih Daerah $\times 100 \%$ Bantuan dan Pinjaman

Tingkat Kemandirian Keuangan Daerah adalah ukuran yang menunjukkan kemampuan keuangan pemerintah daerah dalam membiayai sendiri kegiatanpemerintahan, pembangunan dan pelayanan kepada masyarakat, yang diukur dengan rasio Pendapatan Asli Daerah (PAD) terhadap jumlah bantuan pemerintah pusat dan pinjaman (Bisma, 2010:77).

Secara konsepsional, pola hubungan antara pemerintah pusat dengan pemerintah daerah, harus dilakukan sesuai dengan kemampuan keuangan daerah dalam membiayai pelaksanaan pemerintahan dan pembangunan. Paul Hersey dan Kenneth Blanchard memperkenalkan empat macam pola hubungan hubungan situasional yang dapat digunakan dalam pelaksanaan otonomi daerah (Halim, 2004:188) yaitu:

a) Pola Hubungan Instruktif, peranan pemerintah pusat lebih dominan dari pada kemandirian pemerintah daerah. (Daerah yang tidak mampu melaksanakan otonomi daerah).

b) Pola Hubungan Konsultatif, campur tangan pemerintah pusat sudah mulai 
berkurang, karena daerah dianggap sedikit lebih mampu melaksanakan otonomi daerah.

c) Pola Hubungan Partisipatif, peranan pemerintah pusat semakin berkurang, mengingat daerah yang bersangkutan tingkat kemandiriannya mendekati mampu melaksanakan urusan otonomi.

d) Pola Hubungan Delegatif, campur tangan pemerintah pusat sudah tidak ada karena daerah telah benar-benar mampu dan mandiri dalam melaksanakan urusan otonomi daerah.

Tabel. 2 Pola Hubungan Dan Tingkat Kemampuan Daerah

\begin{tabular}{|c|c|c|}
\hline Kemampuan Keuangan & Kemandirian (\%) & Pola Hubungan \\
\hline $\begin{array}{c}\text { Sebagai pedoman dalam melihat } \\
\text { pola hubungan dengan } \\
\text { kemampuan daerah dari sisi } \\
\text { keuangan dapat dRendah Sekali }\end{array}$ & $0-25$ & Instruktif \\
\hline Rendah & $25-50$ & Konsultatif \\
\hline Sedang & $50-75$ & Partisipatif \\
\hline Tinggi & $75-100$ & Delegatif \\
\hline
\end{tabular}

Sumber: Halim, 2004: 189

\section{Derajat Desentrasi Fiskal}

Untuk menganalisis KemampuanKota Mataram dalam menyelenggara Desentralisasidigunakan formula sebagai berikut : Derajat Desentralisasi $=\frac{\text { PAD Kota Mataram }}{\text { Total Pendapatan Daerah }} \times 100 \%$

Rasio ini menunjukkan kewenangan dan tanggung jawab yang dibirikan pemerintah pusat kepada pemerintah daerah untuk mengelolah pendapatan. Semakin tingg PAD, maka semakin tinggi kemampuan pemerintah daerah dalam menyelenggarakan desentralisasi (Mahmudi, 2010). Menurut artikel yang diterbitkan Kementerian Keuangan (2011), Jika derajat desentralisasi berada di atas
$50 \%$ menunjukkan bahwa pemerintah daerah mampu menyelenggarakan desentralisasi.

Derajat desentralisasi fiskal, khususnya komponen PAD dibandingkan dengan TPD (Total Penerimaan Daerah), menurut hasil penemuan Tim Fisipol UGM menggunakan sekala interval sebagaimana yang terlihat dalam tabel berikut:

Tabel. 3 Kriteria Penilaian Tingkat Desentralisasi Fiskal

\begin{tabular}{|c|c|}
\hline Prosentase PAD terhadap TPD & Tingkat Desentralisasi Fiskal \\
\hline $0,00-10,00$ & Sangat Kurang \\
\hline $10,01-20,00$ & Kurang \\
\hline $20,01-30,00$ & Sedang \\
\hline $30,01-40,00$ & Cukup \\
\hline $40,01-50,00$ & Baik \\
\hline$>50,00$ & Sangat Baik \\
\hline
\end{tabular}

Sumber: Tim Litbang Depdagri - Fisipol UGM, 1991 dalam Bisma (2010:78)

\section{HASIL DAN PEMBAHASAN}

\section{Pendapatan Asli Daerah (PAD) Kota Mataram.}

Pendapatan Asli Daerah (PAD) adalah penerimaan yang berasal dari sumbersumber yang berasal dari wilayah Kota Mataram yang dipungut berdasarkan peraturan daerah yang berlaku :
Sumber-Sumber Pendapatan Asli Daerah bersumber dari :
a. Hasilpajak daerah.
b. Hasil retribusi daerah
c. hasil pengelolaan kekayaan daerah yang dipisahkan


d. Lain lain pendapatan Asli daerah.

Adapun besarnya penerimaan PAD Kota Mataram dapat terlihat pada tabel berikut :

Tabel.4 Perkembangan Penerimaan Pendapata Asli Daerah Kota Mataram Tahun 2012- 2015 (Rp Jutaan)

\begin{tabular}{|l|l|l|}
\hline Tahun & $\begin{array}{l}\text { Pendapatan Asli Daerah } \\
\text { (PAD) (Rp juta) }\end{array}$ & Pertumbuhan (\%) \\
\hline 2012 & 95.877 & 16,47 \\
\hline 2013 & 139.877 & 44,95 \\
\hline 2014 & 202.589 & 44,83 \\
\hline 2015 & 225.076 & 11,10 \\
\hline
\end{tabular}

Sumber : Mataram Dalam Angka diolah.

Berdasarkan pada tabel di atas, diketahui bahwa jumlah PAD kota Meningkat dari tahun 2012 samapai tahun 2015 dengan pertumbuhan yang berpuluktuasi dari pertumbuhan sebesar $16,47 \%$ pada tahun 2012 meningkat secara deratis pada tahun 2013 dan tahun 2014 dengan pertumbuhan $44,95 \%$ dan $44,83 \%$ kemudian turun secara drastis pada tahun
2015 dengan pertumbuhan hanya sebesar $11,10 \%$. Meskipun pertumbuhan PAD berfuluktuasi naman demikian secara absolut meningkat terus daritahun 2012 sebesar Rp95.877.000.000 meningkat menjadi Rp225,076.000.000. Peningkatan PAD ini karena semua sumber penerimaan PAD mengalami peningkatan dari tahun ke tahun.

Tabel.5 Kontribusi Sumber Penerimaan PAD Terhadap Nilai PAD Kota Mataram

\begin{tabular}{|l|l|l|l|l|l|l|}
\hline No & Sumber-Sumber PAD & $\begin{array}{l}\text { Tahun } \\
2012\end{array}$ & $\begin{array}{l}\text { Tahun } \\
2013\end{array}$ & $\begin{array}{l}\text { Tahun } \\
2014\end{array}$ & $\begin{array}{l}\text { Tahun } \\
2015\end{array}$ & $\begin{array}{l}\text { Rata-rata } \\
\text { Kontribusi (\%) }\end{array}$ \\
\hline 1 & Pajak Daerah & 47,56 & 56,75 & 45,29 & 43,03 & 48,15 \\
\hline 2 & Retribusi Daerah & 17,55 & 14,48 & 10,5 & 8,11 & 12,66 \\
\hline 3 & $\begin{array}{l}\text { Hasil Pengelolaan Daerah } \\
\text { yg Dipisahkan }\end{array}$ & 4,84 & 1,97 & 3,70 & 2,76 & 3,31 \\
\hline 4 & Lain-lain PAD & 30,05 & 26,80 & 40,39 & 46,10 & 35,83 \\
\hline
\end{tabular}

Sumber: Data diolah dari Lampiran

Berdasarkan pada tabel di atas diketahui bahwa, kontribusi utama yang dominan mendukung PAD kota Mataram bersumber penerimaanpajak daerah dengan rata-rata kontribusi sebesar $48,15 \%$,lain-lain PAD dengan kontribusi rata-rata sebesar $35,83 \%$, sedangkan kontribusi sumber penerimaan PAD lain jauh lebih rendah dibandingkan kontribusi pajak daerah dan lain-lai PAD seperti retribusi daerah dengan kontribusi 12,66 $\%$ dan hasil pengelolaan daerah yang dipisahkan dengan kontribusi hanya ratarata 3,31\%selama periode 2012-2015.

\section{ANALISIS DATA}

\section{Efektivitas Pemungutan PAD}

Tabel.6 Perkembangan Efektivitas Pemungutan PAD Kota Mataram 2012-2015

\begin{tabular}{|c|c|c|c|c|}
\hline $\begin{array}{c}\text { Tahun } \\
\text { Anggaran }\end{array}$ & $\begin{array}{c}\text { Target } \\
\text { Penerimaan }\end{array}$ & $\begin{array}{c}\text { Realisasi } \\
\text { Penerimaan }\end{array}$ & $\begin{array}{c}\text { Tingkat } \\
\text { Efektivitas (\%) }\end{array}$ & Kriteria \\
\hline 2012 & 65.561 .779 & 95.877 .065 & 146,24 & Sangat efektif \\
\hline 2013 & 124.958 .000 & 139.877 .000 & 111,94 & Sangat efektif \\
\hline 2014 & 160.495 .000 & 202.589 .000 & 126 & Sangat efektif \\
\hline 2015 & 215.600 .000 & 225.076 .000 & 104 & Sangat efektif \\
\hline
\end{tabular}

Sumber : Data diolah dari Lampiran 


\section{Efektivitas Pemungutan Pajak Daerah}

Tabel.7 Perkembangan Efektivitas Pemungutan Pajak Daerah Kota Mataram 2012-2015 dalam Ribuan Rupiah

\begin{tabular}{|c|c|c|c|c|}
\hline $\begin{array}{c}\text { Tahun } \\
\text { Anggaran }\end{array}$ & $\begin{array}{c}\text { Target } \\
\text { Penerimaan }\end{array}$ & $\begin{array}{c}\text { Realisasi } \\
\text { Penerimaan }\end{array}$ & $\begin{array}{c}\text { Tingkat } \\
\text { Efektivitas }(\%)\end{array}$ & Kriteria \\
\hline 2012 & 34.228 .060 & 45.596 .901 & 133,24 & Sangat efektif \\
\hline 2013 & 71.550 .000 & 79.375 .000 & 110,94 & Sangat efektif \\
\hline 2014 & 83.080 .000 & 91.750 .000 & 110 & Sangat efektif \\
\hline 2015 & 92.655 .000 & 96.845 .000 & 105 & Sangat efektif \\
\hline
\end{tabular}

Sumber : Data diolah dari Lampiran

\section{Efektivitas Pemungutan Restribusi Daerah}

Tabel.8 Perkembangan Efektivitas Pemungutan Retribusi Daerah Kota Mataram 2012-2015 dalam Ribuan Rupiah

\begin{tabular}{|l|l|l|l|l|}
\hline Tahun Anggaran & $\begin{array}{l}\text { Target } \\
\text { Penerimaan }\end{array}$ & $\begin{array}{l}\text { Realisasi } \\
\text { Penerimaan }\end{array}$ & $\begin{array}{l}\text { Tingkat } \\
\text { Efektivitas (\%) }\end{array}$ & Kriteria \\
\hline 2012 & 15.593 .719 & 16.825 .137 & 107,90 & Sangat efektif \\
\hline 2013 & 17.824 .000 & 20.251 .000 & 113,62 & Sangat efektif \\
\hline 2014 & 17.918 .000 & 20.964 .000 & 117 & Sangat efektif \\
\hline 2015 & 19.874 .000 & 18.248 .000 & 92 & efektif \\
\hline
\end{tabular}

Sumber : Data diolah dari Lampiran

Merealisasikan pendapatan asli derah, pajak daerah dan retribusi daerah yang direncanakan yang dibandingkan target yang ditetapkan berdasarkan potensi riil daerah. Kemampuan daerah dalam menjalankan tugas dikatakan efektif apabila rasio yang dicapai minimal 1 (satu) atau $100 \%$.

Berdasarkan pengukuran keuangan tersebut maka dapat dilihat hasil perhitungan rasio efektifitas $P A D$, pajak daerah dan retribusi daerahKota Mataram padatahun anggaran 2012-2015 seperti disajikan pada tabel 6 , tabel 7 dan tabel 8 . Berdasarkan tabel 6, tabel 7 dan tabel 8.rasio efektifitas pendapatan asli daerah (PAD) dan pajak daerah dari tahun 2012 sampai tahun 2015 menujukkan rasio efektivitas pemungutan pajak sesuai kriteria termasuk kategori sangat efektif dengan tingkat efektifitas rata-rata berada pada di atas $100 \%$, karena pendapatan yang ditargetkan lebih kecil dari pada realisasinya, atau terjadi under estimate terhadap target yang ditetapkan. Sedangkan efektifitas pemungutan retribusi daerah juga menunjukan kriteria tingkat efektifitasnya adalah sangat efektif pada tahun 2012 sampai tahun 2014 sedangkan pada tahun 2015 termasuk kriteria efektif. Hal ini berarti pemerintah daerahKota Mataram sudah tepat dalam merencanakan PAD, pajak daerah dan retribusikarena mampu merealisasikan PAD yang sudah ditargetkan.

\section{Rasio Kemandirian Keuangan Daerah (Otonomi Fiskal)}

Tabel 9 Perkembangan Perkembangan Rasio Kemandirian Keunngan Daerah Kota Mataram 2012-2015 dalam Ribuan Rupiah

\begin{tabular}{|l|l|l|l|l|l|}
\hline $\begin{array}{l}\text { Tahun } \\
\text { Anggaran }\end{array}$ & Nilai PAD & $\begin{array}{l}\text { Dana } \\
\text { Transfer }\end{array}$ & $\begin{array}{l}\text { Rasio } \\
\text { Kemandirian } \\
(\%)\end{array}$ & $\begin{array}{l}\text { Kriteria } \\
\text { Kemampuan } \\
\text { keuangan } \\
\text { daerah }\end{array}$ & $\begin{array}{l}\text { Pola } \\
\text { Hubungan }\end{array}$ \\
\hline 2012 & 95.877 .065 & 544.998 .107 & 19,03 & Rendah & Insruktif \\
\hline 2013 & 139.877 .000 & 580.925 .000 & 24,08 & Rendah & Konsultatif \\
\hline 2014 & 202.589 .000 & 88.015 .000 & 23,01 & Rendah & Konsultatif \\
\hline
\end{tabular}




\begin{tabular}{|l|l|l|l|l|l|}
\hline 2015 & 225.076 .000 & 963.819 .000 & 23,35 & Rendah & Konsultatif \\
\hline
\end{tabular}

Sumber : Data diolah dari Lampiran

Berdasarkan pada tabel 9, di atas dapat diketahui bahwakemampuan keuangan daerah pada pereode tahun 20122015termasuk dalam kriteria rendah. Berdasarkan pola hubungan antara pemerintah pusat dengan pemerintah daerah diketahui bahwa pada tahun 2012 termasuk dalamPola Hubungan Instruktif karena peranan pemerintah pusat lebih dominan dari pada kemandirian pemerintah daerah(Daerah yang tidak mampu melaksanakan otonomi daerah). Pada tahun 2013 sampai tahun 2015 pola hubungan antara pemerintah pusat dengan pemerintah memperlihatkan pola Hubungan konsultatif yang berarticampur tangan pemerintah pusat sudah mulai berkurang, karena daerah dianggap sedikit lebih mampu melaksanakan otonomi daerah.

\section{Desentralisasi Fiskal}

Ukuran ini menunjukkan kewenangan dan tanggung jawab yang diberikan pemerintah pusat kepada pemerintah daerah untuk menggali dan mengelola pendapatan. Rasio ini dimaksudkan untuk mengukur tingkat kontribusi Pendapatan Asli Daerah sebagai sumber pendapatan yang dikelola sendiri oleh daearah terhadap total penerimaan daerah.

Pendapatan Asli Daerah (PAD) merupakan penerimaan yang berasal dari hasil pajak daerah, retribusi daerah, perusahaan milik daerah dan pengelolaan kekayaan milik daerah serta lainlain pendapatan yang sah.Total Pendapatan Daerah merupakan jumlah dari seluruh penerimaan dalam satu tahun anggaran.

Derajat desentralisasi fiskal, khususnya komponen PAD dibandingkan dengan TPD (Total Penerimaan Daerah), menurut hasil penemuan Tim Fisipol UGM menggunakan sekala interval sebagaimana yang terlihat Bab III.

Tabel.10 Perkembangan Efektivitas Pemungutan PAD Kota Mataram 2012-2015 dalam Ribuan Rupiah

\begin{tabular}{|l|l|l|l|l|}
\hline Tahun Anggaran & $\begin{array}{l}\text { Realisasi } \\
\text { Penerimaan } \\
\text { PAD (000 Rp) }\end{array}$ & $\begin{array}{l}\text { Realisasi } \\
\text { Pendapatan } \\
\text { Daerah (000 Rp) }\end{array}$ & $\begin{array}{l}\text { Derajat } \\
\text { Desentralisasi } \\
\text { Fiskal }\end{array}$ & $\begin{array}{l}\text { Kriteria } \\
\text { Kemampuan } \\
\text { Keuangan daerah }\end{array}$ \\
\hline 2012 & 95.877 .065 & 755.234 .155 & 12,69 & Kurang \\
\hline 2013 & 139.877 .000 & 865.840 .000 & 16,15 & Kurang \\
\hline 2014 & 202.589 .000 & 1.083 .105 .000 & 18,70 & Kurang \\
\hline 2015 & 225.076 .000 & 1.188 .895 .000 & 18,93 & Kurang \\
\hline
\end{tabular}

Sumber : Data diolah dari Lampiran

Berdasarkan tabel 10 di atas diketahui deraja desentrasi fiscal kota Mataram termasuk kriteria tingkat kemampuan keuangan daerah yang kurang dalam periode tahun 2012-2015. Hal dapat menunjukan bahwa keuangan daerah kota Mataram mataram sangat tergantung pada sumber dari penerimaan dari pusat maupun pada tingkat provinsi seperti dana perimbangan dan lain-lain pendapat yang sah seperti hibah, dana bagi hasil dari Provinsi, dan bantuan keuangan dari Provinsi.

\section{KESIMPULAN DAN SARAN}

\section{Kesimpulan}

1. Rasio efektifitas pendapatan asli daerah (PAD) dan pajak daerah dari tahun 2012 sampai tahun 2015 menujukkan rasio efektivitas pemungutan pajak sesuai kriteria termasuk kategori sangat efektif dengan tingkat efektifitasrata-rata beradapada di atas100 \%, karena pendapatan yang ditargetkan lebih kecil dari pada realisasinya, atau terjadi under estimate terhadap target yang ditetapkan. Sedangkan efektifitas pemungutanretribusi daerah juga menunjukan kriteria tingkat efektifitasnya adalah sangat efektif pada tahun 2012 sampai tahun 2014 sedangkan pada tahun 2015 termasuk kriteria efektif. 
2. Kemampuan keuangan daerah pada pereode tahun 2012-2015termasuk dalam kriteria rendah. Berdasarkan pola hubungan antara pemerintah pusat dengan pemerintah daerah diketahui bahwa pada tahun 2012 termasuk dalam Pola Hubungan Instruktif yang menunjukkan peranan pemerintah pusat lebih dominan dari pada kemandirian pemerintah daerah (Daerah yang tidak mampu melaksanakan otonomi daerah). Pada tahun 2013 sampai tahun 2015 pola hubungan antara pemerintah pusat dengan pemerintah memperlihatkan pola Hubungan konsultatif yang berarticampur tangan pemerintah pusat sudah mulai berkurang, karena daerah dianggap sedikit lebih mampu melaksanakan otonomi daerah

3. Derajat desentrasi fiscal kota Mataram termasuk kriteria tingkat kemampuan keuangan daerah yang kurang dalam periode tahun 2012 - 2015, yang menunjukan bahwa keuangan daerah kota Mataramsangat tergantung pada sumberpenerimaan dari pusat maupun pada tingkat provinsi seperti dana perimbangan dan lain -lain pendapat yang sah seperti hibah, dana bagi hasil dari Provinsi, dan bantuan keuangan dari Provinsi.

\section{Saran}

1. Agar penerimaan PAD Kota Mataram semakin meningkat hendak hasil penerimaan yang bersumber dari hasil pengelolaan daerah yang dipisahkan dapat ditingkatkan dengan cara memperbanyak Badan usaha milik daerah (BUMD) dimana selama tahun 2012-2015 kontribusinya terhadap PAD sangat rendah.

2. Keuangan Pemerintah pemerintah Kota Mataram sangat tergantung kepada pemerintah pusat maupun tingkat Provinsi, maka disarankan kepada pemerintah Daerah Kota Mataram senantiasa meningkat penerimaan PADmenggali potensi daerah baik secara intensifikasi maupun ekstensifikasi dan meninjau kemabali tarif pajak daerah dan retribusi daerah.

3. Dalam menetapkan target penerimaan PAD, Pajak daerah dan retibusi daerah hendak realistis dengan tetap memperhatikan potensi seumbersumber penerimaan PAD, pajak Daerah dan retribusi daerahjangan sampai target jauh lebih rendah dari realisasi sehingga merasa berhasil dan akhirnya pemerintah daerah tidak merasa perlu berpaya memaksimalkan sumber-sumber penerimaan PAD.

\section{DAFTAR PUSTAKA}

Adi, Priyo Hari. 2012. Jurnal Studi Pembangunan Interdisiplin Vol. XXI, No. 1. Kemampuan Keuangan Daerah dalam Era Otonomi dan Relevansinya dengan Pertumbuhan Ekonomi (Studi Pada Kabupaten dan Kota se Jawa - Bali).

Bastian, Indra. 2006. Sistem Akuntansi Sektor Publik.

Bisma, I Dewa Gde \& Susanto, Hery. 2010. Jurnal Ganec Swara Edisi Khusus Vol. 4 No. 3. Evaluasi Kinerja Keuangan Daerah Pemerintah Propinsi Nusa Tenggara Barat Tahun Anggaran 2003-3007.

Erlina, Sri Mulyani, 2007. Metedologi Penelitian Bisnis, USU press, Medan.

Ghozalli, Imam, 2005. Aplikasi Analisis Multivariate dengan Program SPSS, Badan Penerbit Universitas Diponegoro, Semarang. , Undang Undang nomor 12 tahun 2008 revisi kedua undang-undang nomor 22 tahun1999 tentang Pemerintahan Daerah , undang-undang nomor 28 tahun 2009 revisi kedua undang-undang nomor 18 tahun 1997 tentang Pajak Daerah dan Retribusi Daerah Peraturan Pemerintah nomo 91 tahun 2010 tentang Pajak Daerah dan Retribusi daerah

Peraturan Mentri Dalam Negeri nomor 37 tahun 2012 Pedoman Penyusunan Anggaran Pendapatan dan Belanja Negara 
Halim, Abdul. (penyunting). 2004. Bunga Rampai Manajemen Keuangan Daerah Edisi Revisi. Yogyakarta: UPP AMP YKPN. 2004. Akuntansi Sektor Publik Akuntansi Keuangan Daerah. Jakarta: Salemba Empat.

, 2014. Manajemen Keuangan Sektor Publik. (Problematika Penerimaan dan Pengeluaran Pemerintah). Jakarta: Salemba Empat.

Mahmudi. 2007. Analisis Laporan Keuangan Pemerintah Daerah. Yogyakarta: Sekolah Tinggi IImu Manajemen YKPN.

Mardiasmo. 2004. Otonomi dan Manajemen Keuangan Daerah. Yogyakarta: ANDI. 2004. Akuntansi Sektor Publik. Yogyakarta. ANDI.

Mahsun, Muhammad. 2013. Pengukuran Kinerja Sektor Publik Edisi Pertama. Yogyakarta: BPFE-Yogyakarta.

$\mathrm{Na}$, Sartina. 2011. Pengaruh desentralisasi fiskal dan Fiscal stress Terhadap pertumbuhan Ekonomi melalui kinerja Keuangan daerah Di kabupaten/kota se-propinsi aceh. Tesis. Medan: Universitas Sumatera Utara.

Nugraha. 2014. Desentralisasi Fiskal di Indonesia (Konsep, Kenyataan dan Tantangan). Bandung.

Purwono, Herry. 2011. Dasar-dasar Perpajakan \& Akuntansi Pajak. Jakarta : Erlangga

Siahaan, Marihot Pahala. 2013. Pajak Daerah \& Retribusi Daerah Edisi Revisi.Jakarta : Rajagrafindo Persada ,2010. Analisis Laporan Keuangan Pemerintah Daerah Edisi Kedua. Yogyakarta: Sekolah Tinggi IImu Manajemen YKPN.

, 2013. Manajemen Kinerja Sektor Publik. Yogyakarta: Sekolah Tinggi IImu Manajemen YKPN.

Tarigan, Raja Malem. 2012. Pengaruh Desentralisasi Dan Pendapatan Perkapita Terhadap Pertumbuhan Ekonomi Pemerintah Kota Provinsi Sumatera Utara. Tesis. Medan: Universitas Sumatera Utara. 